\title{
Solidarity with vulnerable migrants during and beyond the state of crisis
}

\author{
Alessandro Mazzola (a.mazzola@uliege.be) \\ Liège University, Belgium \\ Mattias De Backer (mattias.debacker@kuleuven.be) \\ Liège University/KU Leuven, Belgium
}

COVID-19 brought about a shift in political priorities, pushing refugee issues to the margins. Governments concentrated on measures to contain the pandemic, some of which had strong impact on migration (e.g. closing of borders, halt to asylum applications).

At the same time, the forms of civil society support to migrants emerged since the long summer of migration of 2015 were almost completely stopped. This made even more visible how authorities were ill-prepared-or not concerned at all-to protect vulnerable groups such as refugees, asylum-seekers and undocumented migrants from the pandemic. However, new initiatives emerged, some of which online, others involving small organizations, volunteers, activists and local government personnel in surprising constellations catering for those groups shut out by the response of the government.

We draw on ethnographic fieldwork conducted in Belgium during two crises (the 2015-18 refugee reception crisis and the first wave of the COVID-19 pandemic) to argue that what happened on the ground did not fit in a taxonomy of state (top-down) vs. civil society (bottom-up) solidarity. Instead, many important initiatives took place in an improvised, creative and hybrid fashion, sometimes beyond the original mission of the actors involved. These forms of solidarity bring to the light strong weaknesses within the traditional spaces of state solidarity, and the reality that the two crises are overlapping rather than subsequent: the pandemic further jeopardizes the dramatic context brought about by the reception crisis.

Keywords: refugees and asylum seekers, reception crisis, COVID-19, civil society solidarity, Belgium

\section{Introduction}

Solidarity is "the other face of the crisis" (Cabot, 2016, 152). During the 2008 financial crisis, for example, one could observe the (lack of) solidarity between northern and southern European member states. During the 2015-2018 reception crisis, there were legion examples of citizen solidarity with refugees. During the first wave of the 2020 COVID-19 crisis, quite similar practices of solidarity with vulnerable migrants by groups of citizens, volunteers and NGOs/CSOs emerged. There are some parallels between these crises and governmental responses to them. The 2015 European "refugee crisis" can be read as a "spectacular case of infrastructural failure", which led to "an otherwise largely invisible and occasionally contested asylum infrastructure being placed in the foreground, which under 
regular circumstances should work in the background, effectively and silently" (Meeus et al., 2019, 17) Something similar can be observed about the early days of the COVID-19 pandemic in western Europe.

The spread of COVID-19 in Europe in early 2020 pushed governments to act with urgency and define strategies to control the activity and movement of people. Restrictions were implemented everywhere at local, national and supranational levels, including local and national lockdowns, curfews, the closing of borders and aviation traffic, and even the temporary suspension of international mobility conventions such as the Schengen treaty. Although the refugee issue had been a recurring topic in the public debate in previous years, during the early days of the pandemic, the fate of refugees, asylum-seekers and undocumented migrants did not seem to play any role in the broad strokes of political decisionmaking. If and whenever these groups were mentioned, they were depicted as a problem, as a security and sanitary threat.

Cynically, while the COVID-19 pandemic was experienced as the biggest state of emergency in many decades, from the perspective of vulnerable migrant groups nothing substantially changed: exclusionary measures by the state continued to harmingly impact upon their lives. Governments eventually implemented new exclusionary strategies towards these migrant groups: with few exceptions, initial reactions were oriented at reducing and eventually stopping the arrival of new migrants, such as in the case of Belgium, The Netherlands and Germany where new asylum applications were stopped for an indefinite period of time (Mazzola \& Martiniello, 2020). Restrictions implemented during the first wave of the COVID-19 pandemic also affected the reception of asylum seekers, in the onthe-ground solidarity practices of civil society and citizen initiatives that characterized the refugee reception crisis starting at the "long summer of migration" of 2015 (Hess et al., 2016). The general lockdown led to the closing-in of asylum-seekers in full reception centres, to the rarefaction or disappearance of hospitality of migrants in private residences, to the closure of day and night shelters for homeless and undocumented migrants and to the emergence of various new practices, actors and networks.

This article draws on one research project conducted during and after the 2015-18 reception crisis, and another research project conducted in the first wave of the COVID-19 crisis. The first research is entitled: PUMOMIG - Public opinion, mobilisations and policies concerning asylum seekers and refugees in anti-immigrant times (2017-19), and includes fieldwork in Belgium, Germany, Greece, Hungary, Italy and Sweden (funded by the Belgian Political Science Office BELSPO/BRAIN-be). The data set that informs the findings presented in this paper involves 69 in-depth interviews and numerous observations of field practices conducted in Belgium in 2017-19, when civil society participation was still strong and diversified. Interviews generally focused on pro- and anti-migrant mobilizations and forms of support to asylum seekers starting in 2015, as well as on specific questions exploring the two-way relationship among mobilized citizens (i.e. volunteers and activists), operators of state-designed reception facilities (i.e. social workers, facilitators, reception centre staff), and migrants (asylum seekers, de facto refugees and undocumented migrants). The second research is entitled: Refugee Youth in Public Space - Everyday experiences of young refugees and asylum-seekers in public space (2019-22), and includes fieldwork in Newcastle, Amsterdam, Leipzig and Brussels (funded by HERA - Humanities in the European Research Arena). In this article we will use data from 32 interviews collected in Belgium during March, April and May 2020, in the midst of the COVID-19 lockdown, with a range of frontline practitioners (youth workers, outreach workers, social assistants, basic education teachers, reception centre personnel and personnel of public social services centres CPAS). All names of informants reported in the following sections are anonymized, except for Quentin Courtois (see section three). 
The aim of this paper is to present and discuss the way solidarity with migrants is organized in the context of two subsequent crises, to compare some of the trends, the practices and the solutions adopted by various actors (including citizens, volunteers and activists), and to highlight what this can tell us about solidarity in non-crisis times and about relations between the state and civil society initiatives.

\section{Solidarity with vulnerable migrants}

In this article we will use the term 'vulnerable migrants' to refer to participants in our research who are identified by institutional norms as asylum seekers, de-facto refugees and undocumented migrants. What does solidarity towards vulnerable migrants mean? According to Koos (2019), meanings of solidarity vary extensively, ranging from mutual interdependence and belonging, support for the welfare state, caring for people in need or joint political activism. Solidarity has altruistic, moral, political and humanitarian components, although these are not always clearly distinguishable. Milan \& Pirro (2018) argue that solidarity and altruism can be interpreted as forms of contention ranging from civil disobedience to solidarity action. Mansbridge (1998) defines political solidarity and altruism as a form of public spirit stemming from feelings of empathy or affinity combined with a commitment to principle. According to Giugni (2001), furthermore, the politics of solidarity is often not consciously political, but rather guided by the goal of bringing relief to those who suffer from some kind of injustice.

Interestingly, as Cabot (2016) indicates, while solidarity may be an answer to an external threat which is exclusionary in nature, there is also an exclusionary component within solidarity itself. In this sense, Koos (2019) notes that membership of particular groups often trumps "universal" forms of belonging (Calhoun, 1993) and that exclusion is an integral part of solidarity. Kirchhoff (2020), in that same vein, distinguishes exclusive solidarity among citizens of the same nation state (including support for deportation of those who are not included) from inclusive solidarity which transcends the border of that nation state. We could also refer to this distinction as national-versus-transnational solidarity-Nail $(2012,241)$ calls the latter "nomadic solidarity" - referring to the demand for equality for all regardless of their status. In reality, solidarity practices are often ambivalent, oscillating between both versions.

Solidarity crosses borders, reimagines communities (Rygiel, 2011), challenges dominant systems of authority, enacts alternative imaginaries (Atac et al., 2016), is limited by ideology and legal boundaries (Sarabia, 2020), breaks the law (Tazzioli \& Walters, 2019; Fekete, 2018) and criticizes absurd realities such as the asylum paradox, which entails that refugees have the right to request asylum but, in order to do so, they must first illegally cross borders (Schwiertz \& Schwenken, 2020). In that sense, solidarity is always to a certain extent political, even if the actors involved may portray their actions as apolitical or purely humanitarian, or micro-political (De Backer, 2018 De Backer, forthcoming).

Now, in focusing on solidarity during the $2015-18$ reception crisis, we can see that migration flows towards Europe have been framed in a discourse of crisis, depicting migration as illegitimate and exceptional, and calling for the deployment of emergency measures in order to restore an alleged state of normality (Cantat, 2016). Recent scholarship, furthermore, stresses how civil society solidarity towards migrants is motivated by the fact that governments were ill-prepared to receive and accommodate migrants seeking for international protection (Rea et al., 2019), and this determined a reception crisis (rather than a refugee crisis, as it was labelled in the media and part of the scientific literature) although an increase in asylum applications had been predicted in due time. Significantly, the approach of European countries has been called an "organized non-responsibility" (Pries, 2018), with the aim of highlighting their tendency to shirk responsibility when it comes to 
refugee reception in terms of both implementation of on-the-ground reception practices, and enforcement of legal regulations.

Both the 2015-18 reception crisis and the 2020-2021 COVID-19 crisis are, to a certain extent, exemplary of a conflictual relationship between the state and mobilized civil society. In both cases, it could be argued that the unfolding of events was not predictable which, therefore, mitigated political and institutional responsibilities for the consequent state of crisis. While civil society actors became increasingly vocal as agents of criticism against the weakened public health and social protection structures all around Europe, a debate involving scepticism of capitalism and economic liberalism, cynicism and distrust grew among citizens who no longer trusted the capacity of the state to deal with a global issue and to chart a new way forward (Bauman \& Bordoni, 2014).

In this conflictual relationship, it is hard to distinguish the humanitarian and political dimensions through which solidarity is traditionally described (Fassin, 2011). In the beginning of the 2015-18 reception crisis, the humanitarian principle of solidarity was by far the strongest catalyst for pro-migrant mobilization and had an evident impact on on-theground reception practices. Donations and emergency help such as the distribution of food and clothes were the most common practices among volunteers and civil society groups involved in support activities. In these instances, civil society solidarity resorted under the general definition of humanitarian aid (Barnett \& Weiss, 2008), with its tenets of impartiality, neutrality, independence and shared humanity. However, research on the hospitality of asylum seekers demonstrates how the separation, or even opposition, of humanitarian action and political action is reductive. The term hospitality is employed to identify the fulfilling of the basic needs of migrants, an act that is certainly motivated by the emotion and empathy towards them (Berg \& Fiddian-Qasmiyeh, 2018). Such act, however, takes a political value when observed as an act of cosmopolitan democracy (Archibugi \& Held, 1995), that is a way of conceiving the application of democratic values and rights at the transnational and global level, with no distinction of nationality or legal status.

If it is true that many volunteers and ordinary citizens do not initially act for direct political reasons, the encounter between them and asylum seekers may lead to the politicization of their solidarity engagement (Deleixhe, 2018). Similarly, politicization may occur when civil society groups born in a spontaneous and improvised way to face a state of emergency start to be more organized and coordinated, and begin to structure specific claims such as advocating for the rights of undocumented migrants (Della Porta, 2018). In those instances, researchers have talked of forms of "subversive humanitarianism" to identify solidarity practices as morally motivated actions that are in opposition to the government's political stance or policy agenda (Vandevoordt \& Verschraegen, 2019).

From the above we can conclude that solidarity can refer to a variety of seemingly unrelated things, such as interdependence and belonging, support for the welfare state, caring for people in need or joint political activism (Koos, 2019). Rather than providing a working definition (or a definitive definition for that matter) of what solidarity means, in this paper we present solidarity as a continuum of practices taking shape within the relations between civil society and the state. The aim is to further problematize the concept by stressing its changing and context-dependent nature. This problematization also allows us to discuss the normativity buried in the term, that sense of "positive commitment" that is implicit in the word solidarity, which may obfuscate potentially negative outcomes of the actual practices. Yet, it is clear that this paper focuses predominantly on solidarity initiatives undertaken by civil society professionals or citizens who, out of principle, provide care in a manner that is structured or improvised. Key in the continuum we are describing, is the role played by political awareness and agency, which shapes two sometimes interrelated dynamics that we present below: creative responses, whose main purpose is to 
address the gaps left by the state, and more subversive initiatives involving criticism towards the role of the state.

\section{Solidarity in the $\mathbf{2 0 1 5 - 1 8}$ reception crisis}

Migration and asylum in Belgium are responsibilities of the central Federal government that operates through the Federal Agency for the reception of asylum seekers (Fedasil). The Agency, in turn, is responsible for designing and implementing reception procedures and practices, and managing collective reception structures with its main partner, the Belgian Red Cross. Furthermore, about one-third of the reception network relies on individual reception places managed by local authorities that can enjoy significant autonomy. This multi-levelled governance often resulted in a non-alignment between the national and the local trends in terms of both attitudes towards migrants and participation of the civil society to reception practices. Belgium, in other words, is an example of that "local turn" in the management of migration/asylum that has been highlighted in recent scholarship (Ahouga, 2017; Zapata-Barrero et al., 2017). Not only local authorities, but also and more importantly local groups of citizens who mobilized in favour of migrants paved the way for new and more inclusive paradigms of integration in their specific regions, municipalities and local areas. All that has often gone against the institutional agenda, pretty much concerned with a rather restrictive approach to asylum and migration in general.

In Belgium, numerous people gathered around those areas where migrants concentrated. As we will see below, they often operated as individual volunteers or civil society organizations alongside the state-designated reception actors and structures. In this context, solidarity takes already a hybrid shape as it emerges as a humanitarian act in response to a human emergency, but also as a political act in response to the limitations and gaps of the institutional asylum and reception structure. More than for criticizing or protesting against an anti-migration institutional stance, however, citizens became active to support a reception system that was not working, and was even going to collapse at some of the most critical moments. They often demonstrated a goal in correcting institutional policies and becoming involved in the decision-making process at the local or national level. Most of all, however, solidarity shaped out as very factual as it always resulted in on-the-ground practices of help.

One interesting dimension of the civil society solidarity towards migrants in Belgium concerns the relationship that mobilized actors undertook not only with the migrants they helped out, but also with the physical environment where their practices took place. In other words with the reception space. We use this term to include both formal reception settlements managed by the state-designed actors, and informal settlements. During the 2015-18 reception crisis, individual volunteers, citizen initiatives and organizations entered reception spaces to implement support practices and provide services to asylum seekers. In the context of formal reception centres, these practices and services integrated those provided by the Fedasil and Red Cross managements, but they also addressed issues that were not adequately taken into account by state-designed policies. Tino, a volunteer in the reception centre in Namur, member of the volunteer group Collectif Citoyens Solidaires Namur (CCSN), summed up:

"What we do is based on the principle of the mobilization of skills. This means that you have an expertise, I don't know, you are a lawyer, so you put your expertise available to the residents [of the reception centre]. So we can provide a wide range of services, from legal to medical support, for example. [...] If you are an artist you can step up and organise a workshop, or an art class, everything is useful. It also needs very basic things, if you have a car you can offer a ride to the train station, or to the foreigners' office in Brussels." (Tino, February 2018, own translation) 
Marie-Sophie, a volunteer in the reception centre in Arlon, remarked that solidarity practices were variable and adapted to the needs of migrants, in a perspective of cooperation with the work of the centre's operators:

"Many services are not good enough. I don't blame it on the Red Cross people, it is not an easy job. There's a lot to do, they [the asylum seekers] have so many needs. [...] We meet them to know what they need, but sometimes it is useful to step back from the emergency perspective, and understand that they need just a normal life. For example, one thing l've been doing for a long time is to take some of them to one of my sons' football training. [...] These are things you can't really ask the Red Cross to do. It's the citizen's role, I believe." (Marie-Sophie, October 2018, own translation)

All along the crisis, mobilized citizens acted as mediators between reception spaces and the local context, facilitating the contact with the local population and its social structures. Citizen's initiatives and practices shaped, once again, as hybrid actions straddling humanitarian engagement, civil commitment, and need to integrate-when not completely replace-the government's responsibilities in the asylum issue. This had a great value particularly in those cases where authorities did not give due notice to citizens who were concerned with the opening of a new collective reception centre in their neighbourhood. In this respect, Quentin Courtois, director of the Red Cross reception centres in Namur, affirmed:

"I don't know how we could have managed without them [the volunteers]. It was so important that we had a connection with the city thanks to the volunteers, and could build up a network. They helped us to establish the link, you know, the link with the population in the city, and also around here, around the centre, in the neighbourhood. [...] I know that for many residents it was not easy to accept that a reception centre would open here, in front of their home. The volunteers helped to normalize the situation, for sure." (Quentin Courtois, May 2018, own translation)

Individual volunteers and groups in civil society organizations mobilized as soon as announcements of the opening of the centres were shared, sometimes even before the arrival of the first asylum seekers. The relationship between these mobilized citizens and the reception space began as they provided first-hand logistic support to set up and fit out the accommodation facilities, and collected and distributed basic supplies such as clothing or other non-perishable goods. In a short time, the presence of volunteers became massive, and the management of the centres started to assign them spaces and facilities within the camp structures to better organize support activities. In some cases, civil society organizations had almost complete autonomy in occupying spaces and exploiting facilities in the centres. One of the most successful activities of CCSN was a bi-weekly open-doors day organized to gather citizens and centre's residents together. The initiative was endorsed by the Red Cross management which allowed free circulation of people through the centre's gates and made a large hangar in the site available to volunteers. Tino commented:

"Here is where we do our activities, we gather, we organize classes and workshops, we meet each other for a reason, or for no reason. It's our space and we like it this way, the space where everyone can come for meeting the residents [of the reception centre] and chatting a little bit. [...] We needed a space, definitely. Before, we didn't know how to handle it. A lot of people wanted to participate, to do some activity, and we couldn't really coordinate." (Tino, February 2018, own translation)

Almost all interviewees remarked the need to broaden the reception space by not only taking citizens to the centre, but also by facilitating the encounter between them and the migrants outside the centre, in the city public spaces. In this sense, the motivation to civil 
society solidarity moved from a perspective of reception to a more articulated idea of integration of newcomers into the local social spaces, activities and networks.

Apart from formal centres, civil society also gathered and operated around informal settlements where asylum seekers amassed during the crisis peak. The most known example of this kind in Belgium was the large settlements near the Gare du Nord railway station and Maximilian Park in central Brussels, where migrants lived in extremely precarious conditions with no access to basic services. To make up for the lack of facilities and structures, a large and active civil society organization named Plateforme Citoyenne de Soutien aux Réfugiés was created in Brussels. Similar to other settlements in European cities (Crawley et al., 2017), the support of mobilized citizens in this group included shuttling migrants with private vehicles to their final destination, organizing donations for clothing and basic necessities, and above all distributing food and hosting migrants in private homes. Compared to what happened in formal centres where reception structures were constantly improved, solidarity in non-formal spaces of reception had to face extremely precarious structural conditions. Furthermore, such conditions were visible in the public space and caused discontent in the population, although the settlement was relatively well tolerated. Mobilized citizens played a key mediating role here too, as remarked by Adam, a volunteer in Brussels:

"Yes, it can be shocking for someone to see the settlement here, but I think this can help us to promote awareness, if you see what's going on in your daily space, not just on the television. [...] Not only are the migrants visible here, you can also see the help, those who help. There are the people in need and the people who help them out, and this is important. It's important that the population sees this, how engaged and supportive their fellow citizens are. Bring your friends here at dinnertime, to see the food distribution, or in the evening when volunteers take migrants home for a shower and a rest. Anyone should witness this." (Adam, February 2018, own translation)

The integrating function of the civil society is even more evident in these informal settlements. In particular, volunteers were particularly active in pointing asylum seekers towards migrant organizations and networks in Brussels. These are widely recognized as very important in fostering integration of newcomers and providing them with support services such as legal and employment advice, language support, various forms of training and cultural activities, etc. (Griffiths et al., 2005). Volunteers also became themselves nodal contacts for migrants, by offering the possibility to access their own established personal and professional networks and contacts. They provided the link with public space, and contributed to establish, enlarge and reinforce the social network of migrants. Sarah, a volunteer active in the Belgian province of Luxembourg, pointed out how this has had a great value also in those places where migrant organizations are not as strong and numerous as in larger urban settings:

"Sometimes it is more important to behave like friends, especially when essential needs have been met already, and the reception situation has improved. [...] There are many people here who want to help, but we don't have the same networks and landscape of organizations you have in Brussels, for example. We have to be a bit more creative, so taking the residents [of the reception centre] to the kebab shop in the city is also a form of help. They can take their tea and meet people, maybe compatriot immigrants who have been here for a long time. [...] What will they need, if not becoming part of the community, once they have their status?" (Sarah, November 2018, own translation)

Volunteers helped migrants overcoming isolation and making friends and contacts with whom, to a variable extent, they could establish emotional ties. 
Lastly, but not less importantly, migrants also found support in local citizens to defend their interests and rights throughout the often extremely long procedures of evaluation of their asylum application, and even after the results of the evaluation, whether positive or negative. In this respect, solidarity often clashed with the institutional regulations of the asylum procedure and the legal definition of migrants within this procedure. One important element that clearly emerged from our interviews with mobilized citizens, in-deed, is a strong belief that migrants should not be defined by their status. Accordingly, solidarity and any forms of help have to be given to everyone with no exclusion, including asylum seekers who have not been granted the status of refugees and undocumented migrants. On this matter, individual citizens were often in disagreement not only with institutions, but also with those sector organizations that operated along the institutional regulations and definitions. As it is imaginable, this trend was evident in the context of informal settlements where the concept of legality was constantly questioned by the principles of morality.

\section{Solidarity in the COVID-19 lockdown}

The solidarity mobilizations in civil society and among citizens that surfaced during the 2015-18 reception crisis initially suffered enormously from the COVID-19 pandemic. Although many bottom-up initiatives had developed into more structured and sustainable support organizations, they proved not entirely corona-proof (Mazzola \& Martiniello, 2020). Yet, it can't be argued that formal initiatives and humanitarian services coped better with the unseen sanitary crisis.

In the first days of the lockdown in March 2020, day and night shelters of local authorities closed their doors, as well as food distribution centres and food kitchens. Organizations that stayed open and continued to offer basic amenities suffered from shortages in terms of food and medical supplies. The distribution in the Maximilian Park was closed down by the police and the public dispersed-afterwards it was moved to several other places in the Canal area. From the very first days, along with the sanitary crisis came a food crisis. Particularly devastating for asylum-seekers was the closure of the Immigration Department (Dienst Vreemdelingenzaken DVZ/Office des Étrangers OE, where newcomers are expected to request asylum and are provided with orientation to temporary housing), which also implied that these groups did not obtain information that could guide them to humanitarian help, and the closure of many of the more informal information points. Mieke, who worked as a social assistant:

"We try to see how we can keep in touch digitally with the public, via WhatsApp, Facebook, etc. We also translate the sanitary measures to Arabic and print them or forward them via WhatsApp. There are still people in the street [three weeks after the beginning of the lockdown] that really don't know about anything, that's really crazy. People who have very recently arrived in Belgium and see that everything is closed." (Mieke, April 2020, own translation)

Along with the closure of DVZ/OE came the lack of legal support among asylum-seekers and refugees. Nearly none was offered in asylum-centres, while legal offices and lawyers were only reachable via telephone. Benny, an asylum lawyer: "I notice that when I have concrete questions for people and when I ask their social assistants to reach them, they respond that they have much less insight into where those people are." Legal offices and lawyers normally actively engaged in outreaching work via the asylum centres but that became nearly impossible. Previously, people could come to the permanence hours of the office and ask their question. "To be easily accessible you need to create the space to allow people to bother you. That threshold is higher when you are the one selecting who reaches you" (Benny, April 2020, own translation). 
Several other services had to downgrade their activities to minimal service and many social and humanitarian support organizations switched their personnel to part-time temporary unemployment. But, as Angele, who worked for a social interim office, remarked: "it is absurd that we are all in a system of temporary unemployment while at the same time we have more work than ever. We could use our time to drop by our clients and to see how they are doing" (Angele, May 2020, own translation). Jan, a youth worker: "we work with a minimal team, in order to limit the chance of infections. Everyone is doing their shifts alone" (Jan, April 2020, own translation).

Asylum-centres and institutions for unaccompanied minor refugees closed their doors for visitors, although in some cases residents were allowed to go outside to visit relatives, youth worker Mohamed added. Christian, outreach worker, pointed out that the same applies to people in psychiatric wards or prisons. Jonas, another outreach worker agreed: "prisons are closed for visitors so my colleagues can't go visit and offer assistance to inmates. It's not because these people do not have any contact with the outside world that there aren't any fears" (Jonas, April 2020, own translation). Initiatives usually closed their doors for three reasons: worries about the health of older personnel and volunteers, worries about insurances and unsuitable infrastructure (one clear example of the already failing reception system, remnant of the 2015-2018 reception crisis). Some initiatives managed to stay open by rearranging the use of their spaces: "arrangements were made for the most vulnerable in our population, so people with a certain medical profile, those were isolated, with a separate room and bathroom" (Nicole, asylum-centre employee, March 2020, own translation). However, often this was impossible. At the start of the COVID-19 pandemic, nearly all state-funded asylum-centres were filled to the brim (98 per cent of the capacity of the asylum-centres operated by Fedasil was taken at the start of the first lockdown), while many civil society initiatives did not have the appropriate infrastructure to provide immediate help to a growing group of vulnerable migrants.

Many organizations tried to move (some of) their initiatives and help online, with chat sessions in Facebook video chat, yoga sessions on Zoom or workshops via YouTube. But it is clear that this was not obvious for many vulnerable people. Asylum centres provided improvised psychological support over the telephone, as well as feedback sessions between colleagues. Social assistants tried to keep in touch with their target groups, on top of the busy activities of providing basic amenities.

"Angele: the assistants are so busy with making sure that people's documents are filled out, arranging food distribution or income that they do not have the time to ask how these people are doing. So that is what I do when I call them up. (...) Yet, there is little you can do when you're not near them" (Angele, April 2020, own translation).

Some youth clubs organized WhatsApp sessions, in order to reach out to vulnerable young people in a systematic manner. Others decided to not follow the official guidelines and continued to do their work in public space. For example, Yamina explained that a few outreach workers used social media to communicate to their youths when and where they would be hanging out and where they would be available for a chat. Phillip, an outreach worker, confirmed that also within his organization the team has decided unanimously that people who wanted to continue to work in the streets would be supported by their supervisor. Christian: "why still go in the street? In the first place to make sure that everyone is aware of the government measures and because much misinformation is circulating" (Christian, April 2020, own translation).

Most remarkable during the first weeks of the lockdown was the immense mobilization of volunteers and citizen initiatives and organizations in dealing with the shelter and food crisis among vulnerable migrant groups. Impromptu shelters were organized in hotels, hostels, squats and temporary spaces. Organizations that usually provided leisure or social 
assistance to undocumented migrants, asylum-seekers, refugees and homeless transformed their entire functioning to food distribution, while creating new networks of mixed commercial and humanitarian partners for the provision of basic goods. Improvised shower facilities were installed and several hubs were set up to provide food, access to toilet facilities, Internet and dry clothes. One employee of an organization focusing on newcomers with a precarious residential situation told that:

"We received very distressing signals from families who had no food. We wanted to respond to this, but it grew enormously. Because we also support four squats or collectives of people without legal residence. On top of that, people who did not actually know us but were referred to us via partner organizations or word of mouth, so that has grown immensely in a short space of time. We are now talking about around 500 households. So that takes over our entire operation" (Nelly, April 2020, own translation).

Many of these initiatives were characterized by hybridity, that is, they are hybrid in their work and in their composition. Hybrid initiatives during the COVID-19 crisis consisted of new networks of various partners in the social and cultural sector, partly supported by the local authorities but also by crowdfunding campaigns, coordinated by grassroots organizations or city administration personnel working in their time off, staffed by civil servants, citizens and activists. They consisted of new constellations of co-workers. One hub was run by the personnel of a theatre, an artistic workspace and a day shelter for homeless, another initiative was run by a day shelter, civil servants and volunteers, while being funded by the city council and provided with basic supplies by a network of around ten social and cultural organizations. Although in some cases the local authorities were involved in the establishment, support or funding of these spontaneous and improvised initiatives, there was no central, city-wide coordination.

Yamina: "There is no structure at all, there is no plan at all, as is the case with everything."

Q: "Are there any great initiatives by citizens' organizations that you can think of?"

Yamina: "All initiatives are citizens 'initiatives'." (Yamina, May 2020, own translation)

In these hybrid spaces, new and creative ways to get information to vulnerable groups were developed. Christine, a community worker, summarized some of them:

"Telephone rounds to check whether our local contacts are okay and whether they need help, leaflet rounds with cards urging people to help their neighbours, websites with sanitary measures and information regarding the virus in 20 foreign languages, bicycle tours with a lot of noise and big carts containing food, while tagging along a big sign featuring the URL and telephone number of the information service" (Christine, April 2020, own translation).

Some organizations printed huge posters with basic sanitary information or erected bulletin boards, while others provided homeless and undocumented migrants with copies of the legal framework related to COVID-19, particularly with regard to prohibited activities in public spaces. Numerous citizen collectives and student groups supplied food to vulnerable groups, established street antennas of volunteers hanging out in public space and offered comfort to isolated individuals or single-parent households. Bart, an outreach worker (April 2020, own translation): "we set up an initiative called 'Helping Hands' which engages volunteers from the youth club to offer information to vulnerable groups." Christian (March 2020, own translation): "we provided chill spaces for homeless, with couches 2 metres apart and extension cables to charge mobile phones, where people can still sit inside." 
The hybridity of these networks as well as the improvised nature of these establishments also resulted in new ways of governance. In the Belgian city of Ghent, certificates for homeless and other precarious groups were drafted and provided by a solidarity network. These documents were designed to prove that these people were in the streets because they had nowhere else to go. These documents were circulated by the network without consultation with the police or local authorities. "We simply forced them to accept it," one volunteer remarked (Peter, March 2020, own translation). A similar example of hybrid governance could be found in Brussels where a temporary shelter and leisure space for homeless, which was scheduled to close in April, was reopened by an outreach worker saying: "we'll claim this space for some time longer" (Phillip, April 2020, own translation).

\section{Discussion and conclusion}

What happened on the ground during both the 2015-18 reception crisis and the COVID-19 crisis, disturbed a strict binary of state (top-down) vs. civil society (bottom-up) solidarity. Many important initiatives took place in an improvised, creative and hybrid fashion, sometimes beyond the original mission of the actors involved, involving citizens and institutional subjects either in cooperation or in opposition. Civil society solidarity, particularly during a crisis, brings to the light strong weaknesses within traditional spaces of state solidarity. The question here is how one should understand these weaknesses. Admittedly, it could be argued that certain events leading to a crisis may in themselves be highly unexpectedthat certainly was the case for the COVID-19 pandemic. At the same time, the scale and consequences of such a crisis are usually the result of political decisions taken pre-crisis (such as, for instance, withdrawing funding from the social sector). In other words, the 'crisis vocabulary' allows politicians to redirect attention to circumstances rather than responsibilities.

At first glance, one could say that COVID-19 jeopardized the asylum and reception system in Belgium. Yet, it is probably more accurate to say that the pandemic laid bare an already ill-functioning infrastructure. In short, these two crises are not just successive but largely overlapping, with an 'exceptional' COVID-19 crisis coming on top of the fall-out of the previous one. The COVID-19 crisis showed that the existing infrastructures of care and solidarity for refugees, asylum-seekers and undocumented migrants were insufficient. This showed for instance in reception centres filled to the brim and going into lockdown in March 2020, or in the 'new normal' of day and night shelters for large groups of homeless and undocumented migrants, which first closed their doors during the COVID-19 lockdown, leaving their target groups abandoned in public spaces. Afterwards, outreach workers provided an unseen amount of apartments and rooms in hotels, hostels, squats and corporate buildings (due to sanitary precautions). It was a crisis on top of a normalized crisis.

Initiatives undertaken by citizens and civil society between 2015 and 2018 significantly 'broadened' the formal, state-provided reception network. One could say that civil society increasingly took on responsibilities which we ordinarily ascribe to the state. This had not changed by the time the first wave of the COVID-19 pandemic reached Belgium. Although many of these initiatives have gained some form of permanence, structure and solidity, many of them suffered more substantially from the sudden sanitary measures than older, more established organizations. Several Brussels organizations which saw the light during the reception crisis afterwards suffered severe crises, with one project being accused of 'unfriendly' practices towards female volunteers and another recently suffering from struggles between members of the personnel.

We therefore agree with Rast et al. (2020) that governments not only ought to acknowledge, connect and facilitate the innovative power of local communities, faithbased organizations, volunteers and refugee organizations in the reception process, while 
stopping their own withdrawal in the process. They also have to make sure that these innovative efforts are better integrated in the already existing reception landscape.

Solidarity continues to be shaped in hybrid forms, involving the mobilization of the volunteers' personal and professional skills, alternative forms of communication, and spaces beyond the state-designed formal reception settings. One can indeed argue that this hybridity is a consequence of the institutional gaps in solidarity, a consequence of austerity, 'slim', neoliberal government and disinvestment in social policy. However, it can also be argued that these spaces announce the coming of age of new ways of governing migration (and potentially also new governance of a plethora of other social issues). In the latter case, the strategies adopted during two subsequent crises are simply indicating more effective and resilient modes of interaction with the state, which can also be employed by civil society actors after the crisis.

Civil society solidarity may often be complex and precarious, but there are also advantages and opportunities. The withdrawal of the state has participated in weakening the institutionalized demarcation and categories used to regiment and separate people. The partial retreat of the state from providing care to refugees and other vulnerable migrant groups leads to civil involvement to protect non-citizens, which in turn participates in "destabilising the limited imagination of community associated with state-centred politics" (Cantat \& Feischmidt, 2019, 394). States backing down from terrain usually considered their prerogative allows citizens and civil society to reimagine community and politically challenge the distinction of inside and outside. Indeed, in both crises, mobilized citizens demonstrated a largely inclusive approach going beyond legal status and limitations identifying different categories of migrants.

So, should we consider this spontaneous and hybrid constellation of civic/civil society with parts of the withdrawing state a good example of the governance of the future or will it, in the end, result in further budget cuts in social policy? At this point, it may be best for solidarity workers to politicize their work and pay heed to American rapper and activist Killer Mike's speech after the killing of George Floyd: "now is the time to plot, plan, strategize, organize, and mobilize" (Killer Mike, 2020). It is true that a crisis may not be the perfect time to reflect on reform of or action against the state's dealing with vulnerable migrants groups, if only because of a total lack of time among solidarity workers, but is advisable for civil society initiatives or social researchers to collect experiences and thoughts in the heat of the moment, so as not to forget the immediacy of everyday experiences and their importance for the longue durée. While it may seem ill-advised to criticize the government of whom civil society is also reliant in a state of emergency, it is also important to take into account Jana Bacevic's analysis that crises stifle dissent (Bacevic, 2020). For that purpose, it remains important to keep connecting, discussing, building solidarity and supporting alternative, critical networks. 


\section{References}

Ahouga, Y. (2017). The local turn in migration management: the IOM and the engagement of local authorities. Journal of Ethnic and Migration Studies, 44 (9), 1523-1540.

Archibugi, D. \& Held D. (Eds.) (1995). Cosmopolitan Democracy. An Agenda for a New World Order. Cambridge: Polity Press.

Ataç, I., Rygiel, K. \& Maurice, S. (2016). Introduction: The Contentious Politics of Refugee and Migrant Protest and Solidarity Movements: Remaking Citizenship from the Margins. Citizenship Studies, 20 (5): 527-44.

Bacevic, J. (2020). Never let a serious virus go to waste: solidarity in times of the corona. Retrieved from: https://janabacevic.net/2020/03/13/never-let-a-serious-virus-go-towaste-solidarity-in-times-of-the-corona.

Bauman, Z., \& Bordoni, C. (2014). State of Crisis. Cambridge: Polity Press.

Barnett, M., \& Weiss, T. G. (Eds.) (2008). Humanitarianism in question. Politics, power, ethics. Ithaca and London: Cornell University Press.

Berg, M.L., \& Fiddian-Qasmiyeh, E. (2018). Hospitality and Hostility towards Migrants: Global Perspectives-An Introduction. Migration and Society, 1 (1), 1-6.

Cabot, H. (2016). Contagious' solidarity: reconfiguring care and citizenship in Greece's social clinics. Social Anthropology, 24 (2), 152-66.

Calhoun, C. (1993). Civil Society and the Public Sphere. Public Culture, 5(2), 267-280.

Cantat, C. (2016). Rethinking Mobilities: Solidarity and Migrant Struggles Beyond Narratives of Crisis. Intersections. East European Journal of Society and Politics, 2(4), 11-32.

Cantat, C., \& Feischmidt M. (2019). Conclusion: Civil Involvement in Refugee ProtectionReconfiguring Humanitarianism and Solidarity in Europe. In M. Feischmidt, L. Pries \& C. Cantat (Eds.), Refugee Protection and Civil Society in Europe, (379-99). Cham: Springer.

Crawley, H., Düvell, F., Jones, K., McMahon, S. \& Sigona, N. (2017). Unravelling Europe's 'migration crisis': Journeys over land and sea. London: Policy Press.

De Backer, M. (2018). Regimes of Visibility: Hanging out in Brussels' Public Spaces. Space and Culture, 22(3), 308-20.

De Backer, M. (forthcoming). Micro-politics and the strategies and tactics of visibility. In A. Mubi Brighenti (Ed.), The new politics of visibility: spaces, actors, practices and technologies in the visible. Bristol: Intellect Books.

Deleixhe, M. (2018). L'événement de la rencontre. La Plateforme citoyenne de soutien aux réfugiés en Belgique', Esprit, Juillet-Août, 130-138.

Della Porta, D. (Ed.) (2018). Solidarity Mobilizations in the 'Refugee Crisis'. Contentious Moves. Basingstoke: Palgrave Macmillan. 
Fassin, D. (2011). Humanitarian reason: a moral history of the present. Berkeley and Los Angeles: University of California Press.

Fekete, L. (2018). Migrants, Borders and the Criminalisation of Solidarity in the EU. Race \& Class, 59(4), 65-83.

Giugni, M. (2001). Concluding Remarks: Conceptual Distinctions for the Study of Political Altruism. In M. Giugni \& F. Passy (Eds.), Political Altruism? Solidarity Movements in International Perspective (235-44). Lanham: Rowman \& Littlefield.

Griffiths, D., Sigona, N. \& Zetter, R. (2005). Refugee community organisations and dispersal: Networks, resources and social capital. Bristol: Policy Press.

Hess, S., Kasparek B., Kron S., Rodatz M., Schwertl, M. \& Sontowski, S. (Eds.) (2016). Der lange Sommer der Migration. Berlin/Hamburg: Assoziation A.

Killer Mike (2020). Atlanta, mayor's press conference. Retrieved from: https://www. youtube.com/watch?v=sG0yrng0eY4\&feature=emb_logo\&ab_channel=MichaelDavid Murphy.

Kirchhoff, M. (2020). Differential Solidarity: Protests against Deportations as Structured Contestations over Citizenship. Citizenship Studies, 24(4), 568-86.

Koos, S. (2019). Crises and the Reconfiguration of Solidarities in Europe - Origins, Scope, Variations. European Societies 21(5), 629-48.

Mansbridge, J. (1998). On the Contested Nature of the Public Good. In W. W. Powell \& E. S. Clemens (Eds.), Private Action and the Public Good (3-19). New Haven: Yale University Press.

Mazzola, A., \& Martiniello, M. (2020). "How Covid-19 breaks down solidarity with migrants." The Conversation. Retrieved from: https://theconversation.com/how-covid-19breaks-down-solidarity-with-migrants-135355.

Meeus, B.,van Heur, B. \& Arnaut, K. (2019). Migration and the Infrastructural Politics of Urban Arrival. In B. Meeus, B. van Heur \& K. Arnaut (Eds.), Arrival Infrastructures: Migration and Urban Social Mobilities (1-32). Cham: Springer.

Milan, C., \& A. L. P. Pirro (2018). Interwoven Destinies in the 'Long Migration Summer': Solidarity Movements Along the Western Balkan Route. In D. Della Porta (Ed.), Solidarity Mobilizations in the 'Refugee Crisis': Contentious Moves (125-53). Basingstoke: Palgrave Macmillan.

Nail, T. (2012). Violence at the Borders: Nomadic Solidarity and Non-Status Migrant Resistance. Radical Philosophy Review. 2012.

Pries, E. (2018). Refugees, Civil Society and the State. European Experiences and Global Challenges. Cheltenham: Edward Elgar. 
Rast, M. C. , Younes, Y., Smets, P. \& Ghorashi, H. (2020). The resilience potential of different refugee reception approaches taken during the 'refugee crisis' in Amsterdam. Current Sociology, 68(7), 853-871.

Rea, A., Martiniello, M., Mazzola, A. \& Meuleman, B. (2019). The Refugee Reception Crisis: Polarized Opinions and Mobilizations. Bruxelles: Éditions de l'Université de Bruxelles.

Rygiel, K. (2011). Bordering Solidarities: Migrant Activism and the Politics of Movement and Camps at Calais. Citizenship Studies, 15(1), 1-19.

Sarabia, H. (2020). Migrants, Activists, and the Mexican State: Framing Violence, Rights, and Solidarity along the U.S.-Mexico Border. Citizenship Studies, 24(4), 512-29.

Schwiertz, H., \& Schwenken, H. (2020). Mobilizing for Safe Passages and Escape Aid: Challenging the 'Asylum Paradox' between Active and Activist Citizenship, Humanitarianism and Solidarity. Citizenship Studies, 24(4), 493-511.

Tazzioli, M., \& Walters, W. (2019). Migration, Solidarity and the Limits of Europe. Global Discourse, 9(1), 175-90.

Vandevoordt, R., \& Verschraegen, G (2019). The European Refugee Controversy: Civil Solidarity, Cultural Imaginaries and Political Change, Social Inclusion, 7(2), 48-52.

Zapata-Barrero, R., Caponio, T. \& Scholten, P. (2017). Theorizing the "local turn" in a multilevel governance framework of analysis: a case study in immigrant policies. International Review of Administrative Sciences, 83(2), 241-246. 